\title{
Behçet disease - although rare can be present in children
}

\author{
Aurelia Stancu \\ From 21st European Pediatric Rheumatology (PReS) Congress \\ Belgrade, Serbia. 17-21 September 2014
}

\section{Introduction}

The child's history reveals frequent faringitis accompanied by oral lesions (4-5 episodes/year), billatreal ankle joint swelling and weight loss. Behçet disease (BD) is characterized by a triple-symptom complex of recurrent oral aphthous ulcers, genital ulcers, and uveitis. Hippocrates may have described Behçet disease in the fifth century BC; however, the first description of the syndrome was attributed to the Turkish dermatologist Hulusi Behçet in 1924. In 1930, the Greek physician Adamantiades reported a patient with inflammatory arthritis, oral and genital ulcers, phlebitis, and iritis. Since then, the syndrome has been referred to as Behçet disease.

\section{Objectives}

Behçet disease is most common among persons aged 20-40 years. Cases that develop before age 25 years are more likely to involve eye disease and active clinical disease.The mean age at onset is $25-30$ years.

\section{Methods}

The author present the case of a 16 years adolescent that comes to our office for oral aphthous ulcers (for the last 3 months), genital ulcers and nodular lesions on the legs (for the last month).

\section{Results}

The International Study Group for Behçet's Disease has emphasized the presence of recurrent oral ulcers as a primary consideration in the diagnosis of Behçet disease. In response, the pathogens above have been targeted for study in hopes of establishing a direct link between their presence and disease activity. Unfortunately, researchers

\footnotetext{
Pediatrics, Emergency Childrens Hospital M.S. Curie, Bucharest, Bucharest,
} Romania

(c) 2014 Stancu; licensee BioMed Central Ltd. This is an Open Access article distributed under the terms of the Creative Commons Attribution License (http://creativecommons.org/licenses/by/4.0), which permits unrestricted use, distribution, and reproduction in any medium, provided the original work is properly cited. The Creative Commons Public Domain Dedication waiver (http:// creativecommons.org/publicdomain/zero/1.0/) applies to the data made available in this article, unless otherwise stated. and take full advantage of:

- Convenient online submission

- Thorough peer review

- No space constraints or color figure charges

- Immediate publication on acceptance

- Inclusion in PubMed, CAS, Scopus and Google Scholar

- Research which is freely available for redistribution
C Biomed Central 